\title{
CST5 Gene
}

National Cancer Institute

\section{Source}

National Cancer Institute. CST5 Gene. NCI Thesaurus. Code C159794.

This gene is involved in the inhibition of cathepsins in the oral cavity. 